\title{
Clinical and radiological analysis of the causes for endodontic treatment failure
}

\author{
Jelena Nešković, Milica Jovanović-Medojević, Slavoljub Živković \\ University of Belgrade, Faculty of Dental Medicine, Department of Restorative Odontology and Endodontics, \\ Belgrade, Serbia
}

\begin{abstract}
SUMMARY
Introduction Development of inflammatory lesions or their persistence after primary treatment is considered endodontic failure. The reason for failure can be complex anatomy of the canal system and numerous iatrogenic factors. The objective of this study was to analyze, clinically and radiographically, the causes of primary endodontic treatment failure and assess possibilities for retreatment of teeth with failed endodontic treatment.

Method The study included 79 teeth (36 multirooted and 43 singlerooted tooth) indicated for repeated endodontic treatment. Based on the radiographic assessment of the status of periapical structures, teeth were divided into two groups. The first group included teeth without periapical lesions, i.e. the healthy periodontal tissues (PAI score of 1 and 2) in which retreatment was required for prosthodontic reason due to the poor quality of obturation (28 teeth), and the second group included teeth with visible signs of periapical tissue damage (PAI scores 3, 4 and 5) (51 teeth). In both groups, quality of obturation, coronal sealing and the presence or absence of clinical symptoms was analyzed. Results The most common radiographic finding of definitive obturation was short filling (65.8\% of cases); "forgotten" canals (25.3\%); non-homogeneous obturation with correct length (5.1\%) and fractured instrument (3.8\%). There was significant difference between healthy periodontal ligament and adequate restoration $(P<0.001)$. In $95 \%$ of patients with symptoms, changes in the periapical tissue were observed. Also, there was significant difference in the presence of symptoms after primary treatments, between the teeth with healthy apical periodontal tissue and teeth with periapical lesions $(P=0.019)$.

Conclusion The outcome of the root canal treatment is significantly affected by the quality (density) of obturation and the presence and quality of coronal restoration. In patients with symptoms there were changes in the periapical tissue. Keywords: endodontic failure; obturation; coronal restoration; retreatment
\end{abstract}

\section{INTRODUCTION}

Healing of periapical lesions presented as reduction or disappearance of existing periapical radiolucency is expected after adequately conducted endodontic treatment. However, there are situations when bone repair is absent and there is no reduction in periapical radiolucency, often qualified as endodontic failure [1]. The success rate of endodontic treatment ranges from 53\% - 97\% [2-5]. Higher percentage indicates that almost every endodontic treatment is successful, while lower limit interval suggests that every other is unsuccessful.

Despite the undoubted frequency in everyday clinical practice, there is still no exact definition of endodontic treatment failure. Many clinicians came to the consent that lack of pain and other clinical symptoms or maintained function of endodontically treated teeth are important parameters of successful endodontic treatment [6]. The failure of endodontic treatment includes radiographic appearance of inflammatory lesions in the periapical tissue, which had not existed before or persistence of or enlargement of the radiolucency after undertaken primary treatment $[6,7]$.
The most common reasons for failure are: inadequate control of aseptic conditions [8-15], small access cavity (making difficult to locate all canals so some of them remain "forgotten"); inadequate instrumentation of the root canal, complications during endodontic treatment in the form of perforation of the root canal or separated instruments [16], inadequate obturation (short, non-homogeneous or overextended) [17-20] or microleakage of temporary or definitive coronal restoration [21, 22, 23].

Sometimes failure can occur even if endodontic treatment was properly managed and all procedures are fully respected. The reason for this is the complex anatomy of the canal system and numerous ramifications and anastomoses between the main and accessory canals that cannot be adequately treated or obturated using contemporary instruments, materials and techniques. Noninstrumented region of endodontic space can contain bacteria and necrotic tissue, even when not visible on the X-ray $[12,24]$.

There are factors outside the root canal, within the inflamed periapical tissue that could adversely affect post-operative healing of periapical lesions. Persistence of asymptomatic periapical radiolucency after thorough endodontic therapy can be caused by extra-radicular in-

Address for correspondence: Jelena NEŠKOVIĆ, Department of Restorative Odontology and Endodontics, Faculty of Dental Medicine, University of Belgrade, Rankeova 4, 11000 Belgrade, Serbia; jelenaneskovic74@gmail.com 
fection, true cysts, foreign bodies, the presence of cholesterol crystals or scar healing of the tissue [25].

The aim of this study was to analyze, clinically and radiographically, the causes of primary endodontic treatment failure and assess possibilities for retreatment of teeth with failed endodontic treatment.

\section{METHOD}

The study was conducted at the Clinic of Restorative Odontology and Endodontics, Faculty of Dental Medicine, University of Belgrade, Serbia. All participants signed consent to voluntary participation in the study after introducing with objectives and expected outcomes of the research.

67 patients of both genders, aged 24-79 years, and 79 teeth (36 multirooted and 43 singlerooted tooth) indicated for repeated endodontic treatment were included in the study. One operator carried out clinical trial, while two researchers interpreted the assessment of radiographic outcome.

All 79 teeth had inadequate radiographic obturation and that was the key criterion in the assessment of the failure of endodontic treatment. 52 teeth had short filling while 4 teeth had non-homogeneous filling. "Forgotten" canals were found in 20 teeth while 3 teeth had separated instruments (Table 1). In 36 teeth restoration was adequate or had valid prosthetic restorations, 5 teeth were without fillings a longer period of time, and 43 teeth had inadequate restoration.

Periapical status of each tooth prior to the re-treatment was assessed radiographically using PAI (periapical index) system as follows [26]:

1- PAI normal periapical structures

2- PAI small changes in bone structures that is not pathognomonic for apical periodontitis

3-PAI changes in bone structure with decalcification, characteristic for apical periodontitis

4-PAI periodontitis with clearly defined zone of radiolucency

5-PAI advanced periodontitis with signs of exacerbation and expansion of bone.

PAI score was determined for each tooth individually. $\mathrm{X}$ rays were analyzed on the light box using magnifying lens. Multiroooted teeth were evaluated according to the maximum damage of periodontal structures in any of the roots. Based on the state of periapical structures, teeth

Table 1. Distribution of teeth with endodontic failure in relation to the quality of obturation, coronal restoration and PAI index values. Tabela 1. Distribucija zuba sa endodontskim neuspehom u odnosu na kvalitet opturacije i restauracije i vrednosti PAl indeksa

\begin{tabular}{|c|c|c|c|c|c|c|c|}
\hline \multirow{2}{*}{$\begin{array}{c}\mathbf{A} \\
\mathbf{I}\end{array}$} & \multirow{2}{*}{$\mathbf{N}$} & \multicolumn{5}{|c|}{$\begin{array}{c}\text { Quality of obturation } \\
\text { Kvalitet opturacije }\end{array}$} & \multicolumn{2}{c|}{$\begin{array}{c}\text { Quality of coronal restauration } \\
\text { Kvalitet restauracije }\end{array}$} \\
\cline { 3 - 9 } & & $\begin{array}{c}\text { Short filling } \\
\text { Kratko punjenje }\end{array}$ & $\begin{array}{c}\text { Nonhomogenous filling } \\
\text { Nehomogeno punjenje }\end{array}$ & $\begin{array}{c}\text { Separated instrument } \\
\text { Zalomljen instrument }\end{array}$ & $\begin{array}{c}\text { Missed canals } \\
\text { Zaboravljeni kanal }\end{array}$ & $\begin{array}{c}\text { Adequate } \\
\text { Adekvatno }\end{array}$ & $\begin{array}{c}\text { Inadequate } \\
\text { Neadekvatno }\end{array}$ \\
\hline 1 & 14 & 10 & & & 4 & 12 & 2 \\
\hline 2 & 14 & 10 & & & 4 & 9 & 5 \\
\hline 3 & 29 & 16 & 3 & 1 & 9 & 9 & 20 \\
\hline 4 & 15 & 11 & 1 & 2 & 2 & 3 & 12 \\
\hline 5 & 7 & 5 & & & 20 & 3 & 4 \\
\hline$\Sigma$ & 79 & 52 & 4 & 3 & 36 & 43 \\
\hline
\end{tabular}

Table 2. Distribution of teeth in relation to the presence of clinical symptoms in the group of teeth with healthy periapical tissue and the group with periapical lesions

Tabela 2. Distribucija zuba u odnosu na prisustvo kliničkih simptoma u grupi sa zdravim parodontalnim tkivima i grupi sa periapikalnim lezijama

\begin{tabular}{|c|c|c|c|c|c|}
\hline \multirow{2}{*}{\multicolumn{2}{|c|}{$\begin{array}{l}\text { Clinical symptoms } \\
\text { Klinički simptomi }\end{array}$}} & \multicolumn{2}{|c|}{$\begin{array}{l}\text { Teeth with healthy periapical tissue } \\
\text { Zubi sa zdravim parodoncijumom }\end{array}$} & \multicolumn{2}{|c|}{$\begin{array}{l}\text { Teeth with periapical lesions } \\
\text { Zubi sa periapikalnim lezijama }\end{array}$} \\
\hline & & $N$ & $\%$ & $\mathbf{N}$ & $\%$ \\
\hline \multirow{2}{*}{$\begin{array}{l}\text { Symptoms present } \\
\text { Prisustvo simptoma }\end{array}$} & $\begin{array}{l}\text { Yes } \\
\mathrm{Da}\end{array}$ & 0 & 0,0 & 9 & $36 \%$ \\
\hline & $\begin{array}{l}\mathrm{No} \\
\mathrm{Ne}\end{array}$ & 15 & $100 \%$ & 25 & $64 \%$ \\
\hline \multirow{2}{*}{$\begin{array}{l}\text { Pain } \\
\text { Bol }\end{array}$} & $\begin{array}{l}\text { Yes } \\
\mathrm{Da}\end{array}$ & 0 & 0,0 & 6 & $24 \%$ \\
\hline & $\begin{array}{l}\mathrm{No} \\
\mathrm{Ne}\end{array}$ & 15 & $100 \%$ & 28 & $76 \%$ \\
\hline \multirow{2}{*}{$\begin{array}{l}\text { Sensitivity to percussion } \\
\text { Perkutorna osetljivost }\end{array}$} & $\begin{array}{l}\text { Yes } \\
\mathrm{Da}\end{array}$ & 0 & 0,0 & 3 & $12 \%$ \\
\hline & $\begin{array}{l}\mathrm{No} \\
\mathrm{Ne}\end{array}$ & 15 & $100 \%$ & 31 & $88 \%$ \\
\hline \multirow{2}{*}{$\begin{array}{l}\text { Swelling } \\
\text { Otok }\end{array}$} & $\begin{array}{l}\text { Yes } \\
\mathrm{Da}\end{array}$ & 0 & 0,0 & 3 & $12 \%$ \\
\hline & $\begin{array}{l}\text { No } \\
\mathrm{Ne}\end{array}$ & 15 & $100 \%$ & 31 & $88 \%$ \\
\hline \multirow{2}{*}{$\begin{array}{l}\text { Sinus tract } \\
\text { Fistula }\end{array}$} & $\mathrm{Da}$ & 0 & 0,0 & 3 & $12 \%$ \\
\hline & $\mathrm{Ne}$ & 15 & $100 \%$ & 31 & $88 \%$ \\
\hline
\end{tabular}


were divided into two groups The first group included teeth without periapical changes (PAI score 1 and 2) where retreatment was necessary for prosthetic reasons and poor quality of definitive obturation (28 teeth). The second group included teeth with visible signs of periapical tissue damage (PAI scores 3, 4 and 5) and included 51 teeth.

The second parameter in the analysis was the existence of clinical symptoms after the initial treatment. The first group included cases without clinical symptoms (diagnosed as incidental findings), and the second group included teeth with present clinical symptoms: pain, swelling, sensitivity to percussion, present sinus tract and others (Table 2).

\section{RESULTS}

Results are presented in Figures 1-4 and Tables 3-6.

Periodontal tissues were found healthy (PAI 1 and 2) in $35.4 \%$ of cases, while some changes in periapical tissue (PAI 3, 4 and 5) were recorded in $64.6 \%$ of cases. Short obturation was recorded in $65.8 \%$ of cases, while "forgotten" canals that were detected in $25.3 \%$ of teeth. Non-homogenous filling with correct length was noted in $5.1 \%$ of teeth and fractured instrument was found in the root canal of $3.8 \%$ of analyzed teeth (Table 3 ).

The quality of the coronal seal was inadequate in $54.5 \%$ of cases, while in $45.5 \%$ of cases coronal restorations had satisfactory quality (Table 4). Most of teeth with healthy
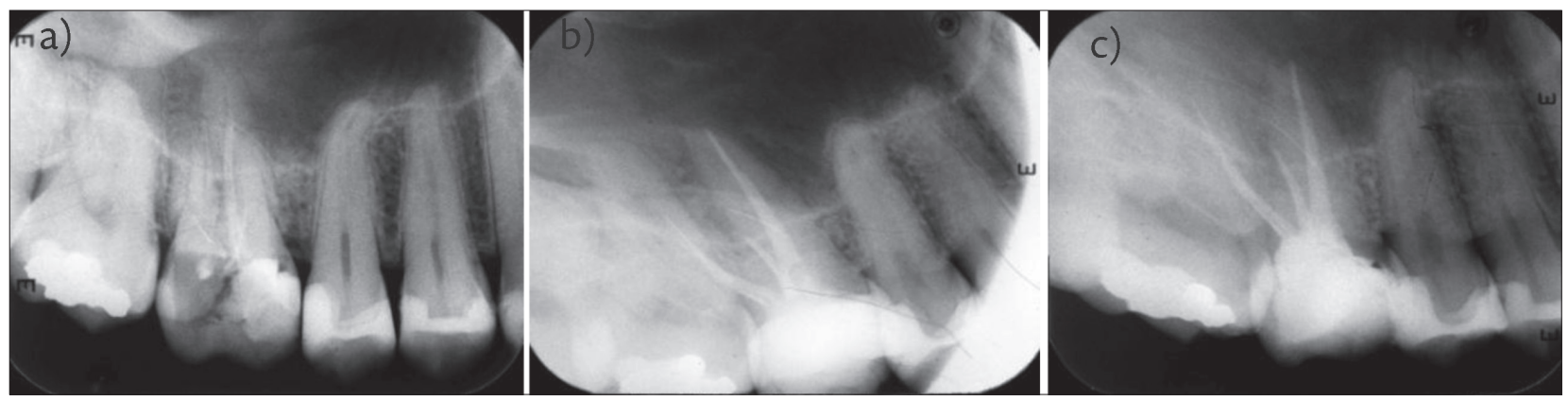

Figure 1. a) Maxillary first molar on the left with inadequate obturation (short, non-homogeneous and forgotten buccomesial canals); b) Final obturation after finished re-treatment; c) After 2 years- complete healing

Slika 1. a) Rendgenografski snimak prvog maksilarnog molara sa leve strane, sa neadekvatnom opturacijom (kratko, nehomogeno punjenje i „zaboravljeni“ bukomezijalni kanali); b) Definitivna opturacija nakon retretmana; c) Potpuno izlečenje posle dve godine
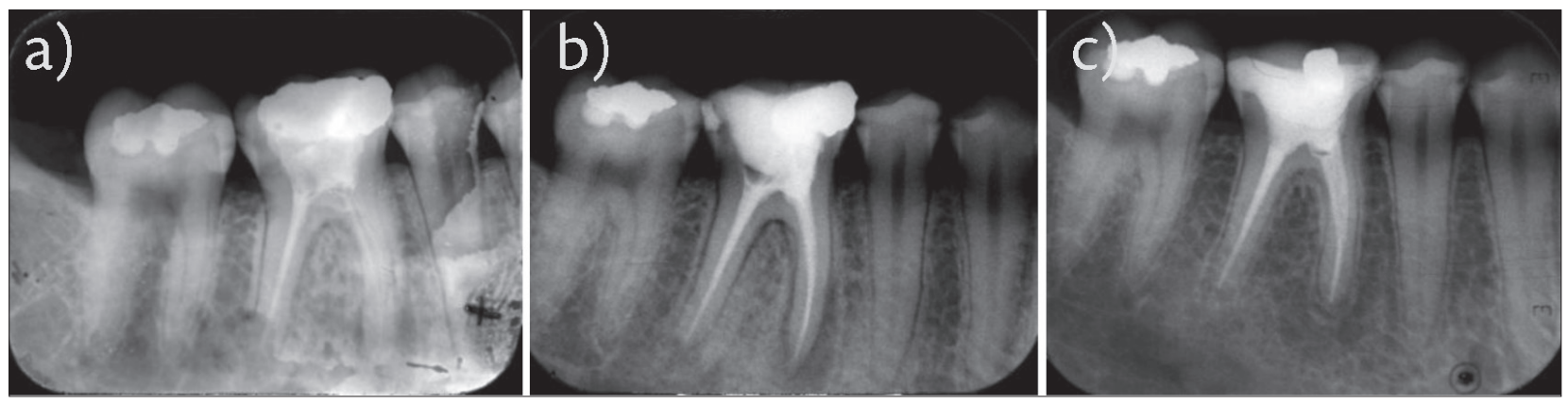

Figure 2. a) Mandibular first molar on the left with inadequate obturation and forgotten mesial canals. The tooth presented clinical symptoms of swelling and tenderness; b) Final obturation after finished re-treatment; c) Complete healing after 2 years

Slika 2. a) Rendgenografski snimak mandibularnog prvog molara sa leve strane (sa neadekvatnom opturacijom i sa „zaboravljenim“ mezijalnim kanalima). Zub je bio sa kliničkim simptomima otoka i bolne osetljivosti; b) Definitivna opturacija nakon retretmana; c) Potpuno izlečenje posle dve godine
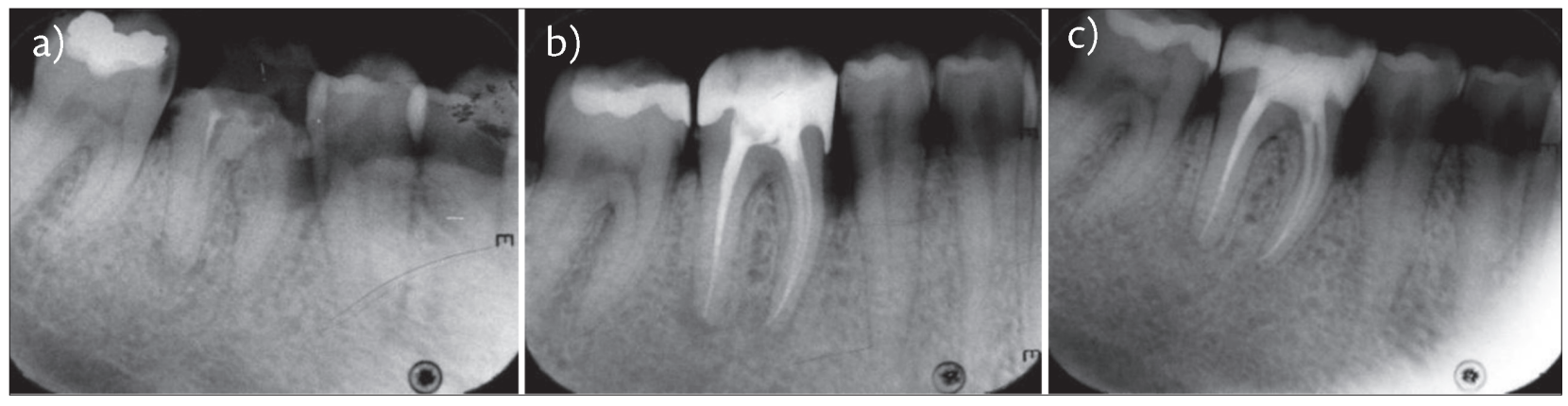

Figure 3. a) Mandibular first molar on the left side with short root canal filling in the distal canal and forgotten mesial canals; b) Final obturation after finished re-treatment; c) Complete healing after 2 years.

Slika 3. a) Rendgenografski snimak mandibularnog prvog molara sa leve strane sa kratkim punjenjem u distalnom kanalu i „zaboravljenim“ mezijalnim kanalima; b) Definitivna opturacija nakon retretmana; c) Potpuno izlečenje posle dve godine 

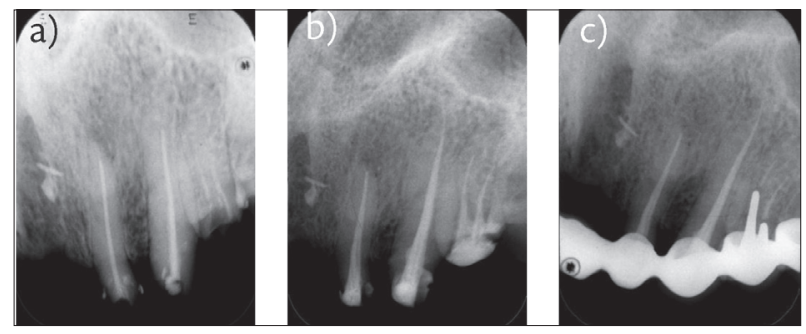

Figure 4. a) Failed endodontic treatment of maxillary lateral incisor, canine and first premolar on the right side. Periapical lesion is visible above the root of lateral incisor; b) Final obturation after finished re-treatment before prosthetic restoration; c) Complete healing after 2 years

Slika 4. a) Radiografski snimak neuspelog endodontskog lečenja na lateralnom sekutiću, očnjaku i prvom premolaru gornje vilice sa desne strane. Periapikalna lezija se uočava iznad korena lateralnog sekutića; b) Definitivna opturacija u okviru preprotetske pripreme pacijenta; c) Potpuno izlečenje nakon dve godine

periapical tiisue (1,2 PAI) were adequately restored ( $75 \%)$, while $70.6 \%$ of the teeth with apical periodontitis (PAI 3, 4,5 ) had inadequate coronal restoration (Table 5).

$\chi 2$ test showed high association between healthy periodontal tissue and adequate restoration on one side and micro leakage of inadequate restoration and periapical changes $(\mathrm{P}<0.001)$ (Table 5)

In regards to the symptoms, $24 \%$ of patients had persistence of the symptoms after the initial endodontic therapy, while the remaining $76 \%$ of cases were asymptomatic. Out of all asymptomatic patients $95 \%$ had some changes in the periapical tissue. Fisher's exact test showed association between the presence of symptoms after initial treatments and teeth with periapical lesions $(\mathrm{P}=0.019)$ (Table 6).

\section{DISCUSSION}

This clinical study was conducted with the aim to analyze the outcomes and causes of the failure of primary endodontic treatments and to facilitate planning for clinicians how to perform retreatment. All cases were selected from everyday clinical practice at the Clinic of Restorative Odontology and Endodontics, School of Dental Medicine, University of Belgrade. A single therapist carried out retreatments.

Consent to participate in the study was signed by 37 patients of both genders, aged 24 to 79 years. Based on the clinical and radiographic examination they required repeated endodontic therapy. The study did not include patients with general diseases and those taking antibiotics in the last 3 months, and teeth with extensive decay destruction or poor periodontal status.

Primary endodontic treatment was done in 2 cases within a year, in 17 cases (34.7\%) 1-5 years before the diagnosis of failure of previous treatment, while in 30 teeth (61\%) primary endodontic treatment was done more than 5 years ago. Endodontically treated teeth have long survival rate in general. In fact, over $60 \%$ of root canal treated teeth are functional for more than 5 years. Salehrabi and

Table 3. Quality of obturation of the primary endodontic treatment in relation to the state of periapical tissue as measured by PAI Index Tabela 3. Kvalitet opturacije primarnog endodontskog tretmana u odnosu na stanje apeksnog parodoncijuma merenog PAI indeksom

\begin{tabular}{|c|c|c|c|c|c|c|c|c|c|c|}
\hline \multirow{3}{*}{$\begin{array}{l}\text { P } \\
\text { A } \\
\text { I }\end{array}$} & \multirow{3}{*}{$\mathbf{N}$} & \multirow{3}{*}{$\%$} & \multicolumn{8}{|c|}{$\begin{array}{l}\text { Quality of obturation } \\
\text { Kvalitet opturacije }\end{array}$} \\
\hline & & & \multicolumn{2}{|c|}{$\begin{array}{c}\text { Short filling } \\
\text { Kratko punjenje }\end{array}$} & \multicolumn{2}{|c|}{$\begin{array}{c}\text { Missed canals } \\
\text { Zaboravljeni kanali }\end{array}$} & \multicolumn{2}{|c|}{$\begin{array}{l}\text { Nonhomogeneous filling } \\
\text { Nehomogeno punjenje }\end{array}$} & \multicolumn{2}{|c|}{$\begin{array}{l}\text { Separated instrumen } \\
\text { Zalomljen instrumen }\end{array}$} \\
\hline & & & $\mathbf{N}$ & $\%$ & $\mathrm{~N}$ & $\%$ & $\mathbf{N}$ & $\%$ & $\mathbf{N}$ & $\%$ \\
\hline 1 & 14 & 17.7 & 10 & 12.6 & 4 & 5.1 & & & & \\
\hline 2 & 14 & 17.7 & 10 & 12.6 & 4 & 5.1 & & & & \\
\hline 3 & 29 & 36.7 & 16 & 20.2 & 9 & 11.4 & 3 & 3.8 & 1 & 1.3 \\
\hline 4 & 15 & 18.9 & 11 & 13.9 & 1 & 1.3 & 1 & 1.3 & 2 & 2.5 \\
\hline 5 & 7 & 8.9 & 5 & 6.3 & 2 & 2.5 & & & & \\
\hline$\Sigma$ & 79 & 100 & 52 & 65.8 & 20 & 25.3 & 4 & 5.1 & 3 & 3.8 \\
\hline
\end{tabular}

Table 4. Quality of coronal restoration in relation to the state of periapical tissue as measured by PAI Index.

Tabela 4. Kvalitet restauracije u odnosu na stanje apeksnog parodoncijuma izraženo PAl indeksom

\begin{tabular}{|c|c|c|c|c|c|c|}
\hline \multirow{2}{*}{$\begin{array}{c}\text { P } \\
\text { A }\end{array}$} & \multirow{2}{*}{$\mathbf{N}$} & \multirow{2}{*}{$\%$} & \multicolumn{3}{|c|}{$\begin{array}{c}\text { Quality of coronal restoration } \\
\text { Kvalitet restauracije }\end{array}$} \\
\cline { 4 - 7 } & & & \multicolumn{2}{|c|}{$\begin{array}{c}\text { Adequate } \\
\text { Adekvatna }\end{array}$} & \multicolumn{2}{c|}{$\begin{array}{c}\text { Inadequate } \\
\text { Neadekvatna }\end{array}$} \\
\cline { 4 - 7 } & & & $\mathbf{N}$ & $\%$ & $\mathbf{N}$ & $\%$ \\
\hline 1 & 14 & 17.7 & 12 & 15.2 & 2 & 2.5 \\
\hline 2 & 14 & 17.7 & 9 & 11.4 & 5 & 6.3 \\
\hline 3 & 29 & 36.7 & 9 & 11.4 & 20 & 25.3 \\
\hline 4 & 15 & 18.9 & 3 & 3.8 & 12 & 15.2 \\
\hline 5 & 7 & 8.9 & 3 & 3.8 & 4 & 5.1 \\
\hline$\Sigma$ & 79 & 100 & 36 & 45.6 & 43 & 54.4 \\
\hline
\end{tabular}

Rotstein (2004) carried out an extensive epidemiological study in the United States on 1,462,936 teeth. After 8 years, $97 \%$ of teeth were still present in the oral cavity [4]. On the other hand, other epidemiological studies [27, $28,29]$ in the recent years indicated that over $30 \%$ of endodonticcally treated teeth were diagnosed with chronic periapical lesions (apical periodontitis) or according to Friedman- "post-treatment endodontic disease" [1].

From a total of 79 teeth, $35 \%$ of the teeth had no visible signs of periapical bone destruction, while in $65 \%$ of teeth the presence of chronic periapical lesions was registered. PCR analysis of the samples taken from the root canals of these teeth after removing old canal filling identified microorganisms in all teeth that had changes 
Table 5. Quality of coronal restoration in relation to the periapical tissue health

Tabela 5. Kvalitet restauracije u odnosu na stanje zdravlja apeksnog parodoncijuma

\begin{tabular}{|l|c|c|c|c|c|c|}
\hline \multirow{2}{*}{$\begin{array}{l}\text { State of periapical tissue } \\
\text { Stanje parodoncijuma }\end{array}$} & \multicolumn{2}{|c|}{$\begin{array}{c}\text { Adequate coronal restauration } \\
\text { Adekvatna restauracija }\end{array}$} & $\begin{array}{c}\text { Inadequate coronal restauration } \\
\text { Neadekvatna restauracija }\end{array}$ & \multicolumn{2}{|c|}{$\begin{array}{c}\text { Total } \\
\text { Ukupno }\end{array}$} \\
\cline { 2 - 7 } & $\mathbf{N}$ & $\%$ & $\mathbf{N}$ & $\%$ & $\mathbf{N}$ & $\%$ \\
\hline $\begin{array}{l}\text { Healthy parodontium } \\
\text { Zdrav parodoncijum PAI 1, 2 }\end{array}$ & 21 & $75 \%$ & 7 & $25 \%$ & 28 & 100 \\
\hline $\begin{array}{l}\text { Periapical lesions } \\
\text { Periapikalne lezije PAI 3, 4, 5 }\end{array}$ & 15 & $29.4 \%$ & 36 & $70.6 \%$ & 51 & 100 \\
\hline$\Sigma$ & 36 & $45.5 \%$ & 43 & $54.5 \%$ & 79 & 100 \\
\hline
\end{tabular}

Table 6. Presence of symptoms after the initial root canal treatment in relation to the state of periapical tissue as measured by PAI index Tabela 6. Prisustvo simptoma nakon primarnog endodontskog lečenja u odnosu na stanje apeksnog parodoncijuma mereno PAI indeksom

\begin{tabular}{|l|c|c|c|c|c|}
\hline \multirow{2}{*}{$\begin{array}{l}\text { State of periapical tissue } \\
\text { Stanje parodoncijuma }\end{array}$} & \multicolumn{2}{|c|}{$\begin{array}{c}\text { Existence of symptoms } \\
\text { Prisustvo simptoma }\end{array}$} & \% & N & \multicolumn{2}{|c|}{$\begin{array}{c}\text { Tithout symptoms } \\
\text { Odsustvo simptoma }\end{array}$} \\
\cline { 2 - 5 } & $\mathbf{N}$ & $1.3 \%$ & 27 & $34.2 \%$ & 28 \\
\hline $\begin{array}{l}\text { Healthy parodontium } \\
\text { Zdrav parodoncijum PAI 1, 2 }\end{array}$ & 1 & $22.8 \%$ & 33 & $41.7 \%$ & 51 \\
\hline $\begin{array}{l}\text { Periapical lesions } \\
\text { Periapikalne lezije PAI 3, 4, 5 }\end{array}$ & 18 & $24 \%$ & 60 & $76 \%$ & 79 \\
\hline$\Sigma$ & 19 & & & \\
\hline
\end{tabular}

in the periapical tissues. The most frequently identified microorganism, E. faecalis, was detected in $94 \%$ of the root canals with chronic periapical lesions.

Only $24 \%$ of patients had clinical symptoms such as pain, swelling, the existence of a sinus tract, or sensitivity to percussion and pain on biting. Most prevalent symptoms were sensitivity to percussion (59\%) as a sign of chronic inflammation of the periapical tissue, and pain ( $47 \%$ of cases) as a sign of acute exacerbation of chronic periapical lesion.

All 79 tooth treated in our study had inadequate obturation. Most frequently registered was short filling in 65\% of cases, "forgotten canals" (25\%), clinically non-homogeneous filling (5.1\%) and the presence of fractured instruments in $3.8 \%$ of canals. Whether inadequately obturated root canal is going to cause the failure of endodontic treatment depends primarily on the presence of bacteria in the root canal. If the vital pulp was treated and coronal restoration properly sealed, impermeable to bacteria, changes in the periradicular tissue will most likely not occur. However, if the canal was infected, an empty space in the apical part of the root will probably cause persistent intraradicular infection or maintain periradicular inflammation after completion of endodontic therapy [8-15].

In addition to the length of the apical canal filling, density ie. hermetic canal filling is an important factor for successful endodontic treatment. Unfortunately, micro computed tomographic studies have shown that even the most modern materials and techniques of instrumentation and obturation are not able to obturate root canal non-porously or to be impermeable to bacteria. Hammad $i$ al. (2009) and Zogheib et al. (2013) measured the volume percentage of voids and trapped air in the apical third of the root canal obturated with Thermafil technique (guttapercha and Topseal) and RealSeal technique (Resilion and RealSeal 1). After scanning and measurement of the volume of voids and unfilled space in obturated root canals, with respect to their total volume, they came to the con- clusion that no technique of obturation provides absolute hermetic sealing of the endodontic space. Furthermore, the difference in the percentage of empty space between the novel adhesive endodontic materials and gutta-percha as gold standard was not statistically significant $[30,31]$.

It is obvious that the quality of obturation affects the outcome of endodontic treatment but this is not the only prerequisite for success. In our study all patients with inadequate obturation were referred to endodontic retreatment, even though $17.7 \%$ of teeth did not have any changes in the periapical tissues (PAI 1), while at $17.7 \%$ of teeth there was slightly enlarged periodontal membrane (which is not pathognomonic finding of apical periodontitits) (PAI 2). In these cases, the retreatment was needed due to prosthetic reconstruction (intraradicular post). Such teeth were adequately restored in $75 \%$ of cases $(21$ out of 28 teeth) that provided good coronal seal, reduced microleakage and prevented (re) infection of the root canal and periapical tissues. Only one tooth with healthy periapical tissue did not have an adequate restoration and showed signs of acute infection (not visible changes on the $x$ ray). Ray and Trope demonstrated that defective coronal restoration and adequate obturation have higher percentage of failures compared to the teeth with appropriate crown restoration and inadequate obturation [23]. Only $9 \%$ of teeth with adequate coronal filling and root canal obturation showed failure, in contrast to the teeth where obturation and coronal restoration were defective where the ratio was $82 \%$. Gillen et al. (2011) conducted a systematic review of available literature about the effect of coronal restoration and root canal obturation and concluded that success of endodontic treatment would be higher if both, endodontic treatment and coronal restoration were done properly [21].

Out of all teeth with changes in the periapical tissue, $84 \%$ had inadequate restoration, and $50 \%$ of them had symptoms indicating the importance of good marginal seal. Similar findings were reported by Liang et al. (2011) 
who used periapical radiography and $\mathrm{CBCT}$ to analyze factors required for successful endodontic treatment. Two years after pulpectomy, periapical radiography showed the presence of periapical lesions in $12.6 \%$, while CBCT detected two times more chronic periapical changes (25.9\%). Interestingly, $80 \%$ of root canal fillings radiographically determined as "short", on CBCT were up to the apical terminus. They also concluded that density and apical extension of the root canal obturation significantly affected the outcome of endodontic treatment as judged by periapical radiographs. By analyzing data obtained by $\mathrm{CBCT}$, for the success of the root canal treatment critical factors were density of the root canal filling and the quality of the coronal restoration [22].

Teeth with healthy periodontal tissue were sent to endodontic retreatment due to radiographically inadequate obturation (part of the preparation for prosthodontic rehabilitation) or were detected as incidental finding. Dilemma of whether teeth with inadequate obturation, healthy periapical tissue and without clinical signs and symptoms, should be retreated, is always current among endodontists. If tooth has already adequate restoration, it can be monitored by regular check-ups. However, if the tooth is planned to support fixed prosthodontic construction, with intraradicalar post, retreatment is strongly recommended [32]. Success of repeated endodontic treatment relies on: proper diagnosis of the endodontic failure (periapical radiography, CBCT), adequate desopturation and repeated cleaning and shaping of the canal (the expertise of the therapist, instruments and materials), highquality three-dimensional hermetic obturation of the root canal system, and timely and adhesive restoration placement after retreatment is finished.

\section{CONCLUSION}

The outcome of the root canal treatment is significantly affected by the quality (density) of root canal obturation and the presence and good quality of the coronal restoration. Most teeth with healthy periodontal tissue at the time of diagnosis of the failure of primary endodontic treatment were adequately restored. However, most teeth with changes in the periapical tissue had inadequate coronal restoration. Teeth in patients who had symptoms mostly had visible changes in the periapical tissue.

\section{REFERENCES}

1. Friedman S, Mor C. The success of endodontic therapy- healing and functionality. J Calif Dent Assoc. 2004; 32(6):493-503. [PMID: 15344440]

2. Chu FC, Tsang CS, Chow TW, Samaranayake LP. Identification of cultivable microorganismus from primary endodontic infections with exposed and unexposed pulp space. J Endod. 2005; 31(6):424-9. [PMID: 15917680]

3. Friedman S. Consideration and consepts of case selection in the management of post-treatment endodontic disease ( treatment failure). Endod Top. 2002; 1:54-78. [DOI: 10.1034/j.16011546.2002.10105.x]
4. Salehrabi R, Rotstein I. Endodontic treatment outcomes in a large patient population in the USA: an epidemiological study. J Endod. 2004; 30:846-50. [DOI: 10.1097/01.don.0000145031.04236.ca]

5. Sjögren U, Figdor D, Persson S, Sundquist G. Influence of infection at the time of root filling on the outcome of endodontic treatment of teeth with apical periodontitis. Int Endod J. 1997; 30(5):297-306. Erratum in Int Endod J. 1998; 31:131-48. [PMID: 9477818]

6. Seltzer S. Root canal failure in endodontology. 2nd ed. 1988. p. 439-70.

7. Daokar S, Kalekar A. Endodontic failures-a review IOSR. J Dent Med Sci. 2013; 4:5-10

8. Haapasalo MP, Endal U, Zandi H, Coil JM. Eradiction of endodntic infection by instrumentation and irrigation solutions. Endod Topics. 2005; 10:77-102. [DOI: 10.1111/j.1601-1546.2005.00135.x]

9. Nair PNR, Henry S, Cano V, Vera J. Microbial status of apical root canal system of human mandibular first molars with primary apical periodontitis after "one-visit" endodontic treatment. Oral Surg Oral Med Oral Pathol Oral Radiol Endod. 2005; 99(2):231-52. [DOl: 10.1016/j.tripleo.2004.10.005] [PMID: 15660098]

10. Ricucci D, Siqueira JFJr, Bate Al, Pitt ford TR. Histologic investigation of root canal treated teeth with apical periodontitis: a retrospective study from twenty-four patients. I Endod. 2009; 35(4):493-502. [DOl: 10.1016/j.joen.2008.12.014] [PMID: 19345793]

11. Ricucci D, Siqueira JFJr. Biofilms and apical periodontitis: study of prevalence and association with clinical and histopathologic findings. J Endod. 2010; 36:1277-88. [DOI: 10.1016/j.joen.2010.04.007]

12. Ricucci D, Siqueira JFJr. Fate of the tissue in lateral canals and apical ramification in response to pathologic conditions and treatment procedures. J Endod. 2010; 36(1):1-15. [DOI: 10.1016/j. joen.2009.09.03818] [PMID: 20003929]

13. Siqueira JFJr, Rocas IN. Polymerase chain reaction-based analysis of microorganisms associated with failed endodontic treatment. Oral Surg Oral Med Oral Pathol Oral Radiol Endod. 2004; 97(1):85-94. [DOI: 10.1016/S1079210403003536] [PMID: 14716262]

14. Sundquist G, Figdor D. Life as endodntic pathogene. Ecological differences between the untreated and root filled canals. Endod Topics. 2003; 6:3-28. [DOI: 10.1111/j.1601-1546.2003.00054.x]

15. Waltimo T, trope M, HaapasaloM, Orstavik D. Clinical efficacy of treatment procedures in endodontic infection control and one year follow-up of periapical healing. J Endod. 2005; 31(12):863-6. [PMID: 16306819]

16. Torabinejad M, Lemon RL. Procedural accidents. Principles and Practice of Endodontics. 1996; 306-23.

17. Simon S, Machtou P, Tomson P, Adams N, Lumley P. Influence of fractured instruments on the success rate of endodontic treatment. Dent Update. 2008; 35(3):172-4, 176, 178-9. [PMID: 18507225]

18. Ramachandran Nair PN, Pajarola G, Schroeder HE. Types and incidence of human periapical lesions obtained with extracted teeth. Oral Surg Oral Med Oral Pathol. 1996; 81(1):93-102. [PMID: 8850492]

19. Ng Y-L, Mann V, Gulabivala K. A prospective study of the factors affecting outcomes of nonsurgical root canal treatment: part 1: periapical health. Int Endod J. 2011; 44(7): 583-609. [DOI: 10.1111/j.1365-2591.2011.01872.x] [PMID: 21366626]

20. Siqueira JF. Aethiology of root canal treatment failure: why well-treated teeth can fail. Int Endod J. 2001; 34(1):1-10. [DOI: 10.1046/j.1365-2591.2001.00396.x] [PMID: 11307374]

21. Gillen BM, Looney SW, Gu LS, Loushine BA, Weller RN, Loushine RJ, et al. Impact of the quality of coronal restoration versus the quality of root canal fillings on success of root canal treatment: a systematic review and meta-analysis. J Endod. 2011; 37(7): 895-902. [DOI: 10.1016/j.joen.2011.04.002] [PMID: 21689541]

22. Liang YH, Li G, Wesselink PR, Wu MK. Endodntic outcome predictors identified with periapical radiographs and cone-beam computed tomography scans. J Endod. 2011; 37(3):326-31. [DOI: 10.1016/j.joen.2010.11.032] [PMID: 21329816]

23. Ray HA, Trope M. Periapical status of endodontically treated teeth in relation to the technical quality of the root filling and the coronal restoration. Int Endod J. 1995; 28(1):12-8. [DOI: 10.1111/j.13652591.1995.tb00150.x] [PMID: 7642323] 
24. Endal U, Shen Y, Knut A, Gao Y, Haapasalo M. A high resolution computed tomographic study of changes in root canal isthmus area by instrumentation and root filling. J Endod. 2011; 37(2):2237. [DOI: 10.1016/j.joen.2010.10.01219] [PMID: 21238806]

25. Nair PNR. On the causes of persistent apical periodontitis: a review. Int Endod J. 2006; 39(4):249-81. [DOI: 10.1111/j.13652591.2006.01099.x] [PMID: 16584489]

26. Ǿrstavik D, Kerekes K, Eriksen HM. The periapical index: A scoring system for radiographic assessment o apical periododntitis. Dent Traum. 1986; 2(1):20-34. [DOI: 10.1111/j.1600-9657.1986. tb00119.x] [PMID: 3457698]

27. Boucher Y, Matossian L, Rilliard F, Macthov P. Radiographic evaluation of the prevalence and technical quality of root canal treatment in a French subpopulation. Int Endod J. 2002; 35(3):229-38. [DOI: 10.1046/j.1365-2591.2002.00469.x] [PMID: 11985674]

28. Dugas NN, Lawrance HP, Teplitsky PE, Pharoah MJ, Friedman S. Periapical health and treatment quality assesement of root-filled teeth in two Canadian populations. Int Endod J. 2003; 36(3):18192. [DOI: 10.1046/j.1365-2591.2003.00640.x] [PMID: 12657144]
29. Farzaneh M, Abitol S, Friedman S. Treatment Outcome in Endodontics: The Toronto Study. Phases I and II: Orthograde retreatment. J Endod. 2004; 30(9):627-33. [PMID: 15329565]

30. Hammad M, Qualtrough A, Silikas N. Evaluation of root canal obturation: a three-dimensional in vitro study. J Endod. 2009; 35(4):541-4. [DOl: 10.1016/j.joen.2008.12.021] [PMID: 19345801]

31. Zogheib C, Naaman A, Sigurdsson A, Medioni E, Bourbouze G, Arbab-Chirani R. Comparative micro-computed tomographic evaluation of two carrier-based obturation systems Clin Oral Invest. 2013; 17(8):1879-83. [DOl: 10.1007/s00784-012-0875-1] [PMID: 23114880]

32. Ruddle C). Nonsurgical retreatment J Endod. 2004; 30(12):827-45. [DOI: 10.1097/01.don.0000145033.15701.2d20] [PMID: 15564860]

Received: 03.02.2017 • Accepted: 08.05.2017 


\title{
Uzroci neuspeha endodontskog lečenja zuba
}

\author{
Jelena Nešković, Milica Jovanović-Medojević, Slavoljub Živković \\ Univerzitet u Beogradu, Stomatološki fakultet, Klinika za bolesti zuba i endodonciju, Beograd, Srbija
}

\begin{abstract}
KRATAK SADRŽAJ
Uvod Neuspehom endodontskog lečenja smatra se pojava radiografskog nalaza inflamatorne lezije, odnosno njeno perzistiranje ili uvećanje posle preduzete primarne endodontske terapije. Razlog za neuspeh mogu biti kompleksna anatomija kanalnog sistema, ali i brojni jatrogeni faktori.

Cilj ovog rada je bio da se kod zuba sa neuspelim endodontskim lečenjem klinički i radiografski analizira uzrok neuspeha primarnog endodontskog tretmana i procene mogućnosti za ponovni endodontski zahvat.

Metod rada U ovo istraživanje je uključeno 79 zuba (36 višekorenih i 43 jednokorena zuba) indikovanih za ponovljeni endodontski tretman. Na osnovu radiografske ocene stanja periapikalnih struktura zubi su podeljeni u dve grupe: prvu grupu su činili zubi bez periapikalnih promena, tj. sa zdravim parodoncijumom (PAl skor $1 \mathrm{i}$ 2) kod kojih je retretman bio neophodan iz protetskih razloga zbog lošeg kvaliteta definitivne opturacije (28 zuba), a drugu zubi sa vidljivim znacima oštećenja apeksnog parodoncijuma (PAI skor 3 , 4 i 5) (51 zub). U obe grupe analiziran je kvalitet opturacije, kvalitet kruničnog zaptivanja i prisustvo ili odsustvo kliničkih simptoma. Rezultati Najčešći radiografski nalazi kvaliteta definitivne opturacije kanala bili su: kratko punjenje (65,8\% slučajeva), „zaboravljeni“ kanali (25,3\%), klinički nehomogeno punjenje uz korektnu dužinu definitivnog punjenja $(5,1 \%)$ i frakturiran instrument (3,8\%). Nađena je statistički visoko značajna razlika između adekvatne restauracije i zdravog parodoncijuma, odnosno pojave mikrocurenja zbog neadekvatne restauracije i periapikalnih promena $(p<0,001)$. Kod $95 \%$ pacijenata sa simptomima uočene su promene $u$ apeksnom parodoncijumu. Takođe, nađena je statistički značajna razlika u prisustvu simptoma nakon primarne endodontske terapije između zuba sa zdravim parodoncijumom i zuba sa periapikalnim lezijama $(p=0,019)$

Zaključak $\mathrm{Na}$ ishod endodontskog lečenja značajno utiču kvalitet (hermetičnost) opturacije kanala korena, odnosno prisusutvo i kvalitet koronarne restauracije. Kod pacijenata sa simptomima uglavnom su postojale i promene $u$ apeksnom parodoncijumu nakon endodontskog lečenja.
\end{abstract}

Ključne reči: endodontski neuspeh; opturacija; restauracija

\section{UVOD}

Nakon adekvatno sprovedenog endodontskog tretmana očekuje se zarastanje, odnosno smanjenje ili iščezavanje postojećeg rasvetljenja iznad vrha korena na kontrolnim radiografijama. Međutim, postoje situacije kada koštana reparacija izostaje i ne dolazi do smanjenja periapikalnog rasvetljenja, pa se to često kvalifikuje kao endodontski neuspeh [1]. Stopa uspešnosti endodontske terapije kreće se od 53\% do 97\% [2-5].Viši procenat ukazuje na to da je skoro svaki endodontski tretman uspešan, dok niža granica intervala sugeriše da je svaki drugi neuspešan.

Uprkos nesumnjivoj učestalosti u svakodnevnoj kliničkoj praksi, među endodontistima još uvek ne postoji tačna definicija neuspeha endodontskog lečenja. Mnogi kliničari bi se složili da odsustvo bola i drugih kliničkih simptoma, odnosno očuvanost funkcije endodontski lečenog zuba, proglase važnim parametrom uspeha endodontskog tretmana [6]. Neuspehom endodontskog lečenja se smatra postojanje radiografskog nalaza inflamatorne lezije u apeksnom parodoncijumu koja ranije nije postojala, odnosno njeno perzistiranje ili uvećanje posle preduzete primarne endodontske terapije $[6,7]$.

Istraživanja ukazuju da su najčešći razlozi neuspeha: neadekvatna kontrola aseptičnih uslova rada [8-15], nedovoljno ekstendiran pristupni kavitet (koji onemogućava pronalaženje svih kanala pa pojedini ostaju ,zaboravljeni“ i neobrađeni), neadekvatna instrumentacija kanala, komplikacije tokom endodontskog tretmana u vidu perforacije korena ili frakture kanalnih instrumenata [16], neadekvatna opturacija kanalnog sistema (nedovoljna apikalna ekstenzija punjenja, nehomogeno punjenje ili preekstendirano kanalno punjenje) [17-20], odnosno mikrocurenje privremenih ili definitivnih koronarnih restauracija $[21,22,23]$.
Ponekad se neuspeh može javiti i onda kada je endodontska terapija korektno vođena i sve procedure potpuno ispoštovane. Razlog za to je kompleksna anatomija kanalnog sistema i brojne ramifikacije i anastomoze između glavnog i akcesornih kanala koje se ne mogu adekvatno obraditi niti opturisati postojećim instrumentima, materijalima i tehnikama. Neinstrumentirane regije endodontskog prostora mogu sadržati bakterije i nekrotično tkivo čak i onda kada se čini da je opturacija kanala radiografski korektna [12, 24].

I na kraju, postoje ekstraradikularni faktori izvan kanala korena, u okviru inflamiranog periapikalnog tkiva koji mogu negativno uticati na postoperativno zarastanje periapikalnih lezija. Asimptomatsko perzistiranje radiografskog rasvetljenja iznad vrha korena nakon adekvatno sprovedene endodontske terapije mogu uzrokovati: ekstraradikularna infekcija, prave ciste, strana tela, prisustvo kristala holesterola ili ožiljno zarastanje tkiva [25].

Cilj ovog rada je bio da se kod zuba sa neuspelim endodontskim lečenjem klinički i radiografski analizira uzrok neuspeha primarnog endodontskog tretmana i procene mogućnosti za ponovni endodontski zahvat.

\section{METOD RADA}

Studija je sprovedena na Klinici za bolesti zuba i endodonciju Stomatološkog fakulteta Univerziteta u Beogradu. Nakon što su upoznati sa ciljevima i očekivanim ishodima istraživanja, svi učesnici su potpisali pristanak da dobrovoljno učestvuju u istraživanju.

U ovo istraživanje je uključeno 67 pacijenata oba pola starosti od 24 do 79 godina, odnosno 79 zuba (36 višekorenih i 43 jednokorena zuba) indikovanih za ponovljeni endodontski 
tretman. Kliničko ispitivanje je sprovedeno od strane jednog operatera, dok su radiografsku procenu ishoda lečenja tumačila dva istraživača.

Svih 79 zuba imalo je radiografski nalaz neadekvatne opturacije jer je to bio ključni kriterijum u oceni neuspeha endodontskog lečenja. S obzirom na to da su sve opturacije bile nezadovoljavajućeg nivoa, njihov kvalitet je ocenjen kao kratko punjenje (52 zuba), nehomogeno punjenje (četiri zuba), prisustvo „Zaboravljenih“ kanala (20 zuba) i zalomljeni instrumenti (tri zuba) (Tabela 1). Kod 36 zuba uočena je adekvatna restauracija ili validna protetska nadoknada, pet zuba je bilo bez ispuna duži vremenski period, a kod 43 zuba je uočena neadekvatna restauracija.

Periapikalni status svakog zuba pre početka retretmana procenjivan je radiografski pomoću PAI (periapikalni indeks) sistema za skoriranje na sledeći način [26]:

PAI 1 - normalne periapikalne strukture

PAI 2 - male promene u strukturi kosti koje nisu patognomonične za apikalni periodontitis

PAI 3 - promene u koštanoj strukturi sa dekalcifikacijom karakterističnom za apikalni periodontitis

PAI 4 - periodontitis sa jasno definisanom zonom rasvetljenja

PAI 5 - uznapredovao periodontitis sa znacima egzacerbacije i ekspanzije kosti.

PAI skor je određen za svaki zub pojedinačno, a radiografski nalaz je analiziran na negatoskopu uz primenu uveličavajuće lupe. Višekoreni zubi su ocenjivani u skladu sa najvećim oštećenjem parodontalnih struktura na jednom od korenova.

$\mathrm{Na}$ osnovu radiografske ocene stanja periapikalnih struktura zubi su podeljeni u dve grupe. U prvu grupu su svrstani zubi bez periapikalnih promena, tj. sa zdravim parodoncijumom (PAI skor 1 i 2), kod kojih je retretman bio neophodan iz protetskih razloga - zbog lošeg kvaliteta definitivne opturacije (28 zuba). Drugu grupu, koja je obuhvatila 51 zub, činili su zubi sa vidljivim znacima oštećenja apeksnog parodoncijuma (PAI skor 3, 4 i 5).

Drugi parametar u analizi bio je postojanje kliničkih simptoma nakon inicijalnog tretmana. Prvu grupu su činili slučajevi bez kliničkih simptoma (dijagnoza postavljena slučajnim nalazom), a drugu slučajevi sa kliničkim simptomima u vidu bola, otoka, perkutorne osetljivosti, odnosno postojanja fistule (Tabela 2).

\section{REZULTATI}

Dobijeni rezultati prikazani su u tabelama 3-6 i slikama 1-4.

Parodontalna tkiva su notirana kao zdrava (PAI 1 i 2) u $35,4 \%$ slučajeva, dok su destruktivne pomene u periradikularnim parodontalnim tkivima (PAI 3, 4 i 5) zabeležene u 64,6\% slučajeva.

Najčešći radiografski nalaz kvaliteta definitivne opturacije kanala zatečen u momentu dijagnostikovanja neuspeha endodontskog lečenja bio je kratko punjenje, koje je zabeleženo u 65,8\% slučajeva, a zatim slede „zaboravljeni“ kanali, koji su detektovani u 25,3\% zuba. Klinički nehomogeno punjenje uz korektnu dužinu definitivnog punjenja nađeno je kod 5,1\% zuba, dok je u 3,8\% slučajeva na radiografiji uočen frakturirani instrument u kanalu korena (Tabela 3).

Kvalitet kruničnog zaptivanja, odnosno restauracije zuba u momentu dijagnoze neuspeha endodontskog lečenja je u 54,5\% slučajeva bio neadekvatan, dok su u 45,5\% slučajeva krunični ispuni bili zadovoljavajućeg kvaliteta (Tabela 4). Većina zuba sa zdravim parodoncijumom (PAI 1,2) bila je adekvatno restaurirana (75\%), dok je 70,6\% zuba sa obolelim apeksnim parodoncijumom (PAI 3, 4, 5) imalo neadekvatne krunične restauracije (Tabela 4).

U grupi zuba sa zdravim parodontalnim tkivima $75 \%$ zuba je imalo adekvatnu koronarnu restauraciju, dok kod 25\% krunično rubno zatvaranje nije bilo zadovoljavajućeg kvaliteta. Kod zuba sa hroničnim promenama u apeksnom parodoncijumu 70,6\% koronarnih restauracija u momentu dijagnostikovanja neuspeha endodontske terapije nije bilo adekvatno, dok je krunično zaptivanje bilo zadovoljavajuće u 29,4\% zuba sa HAP-om (Tabela 5).

Analizom kvaliteta kruničnog zaptivanja i pojave promena $\mathrm{u}$ apeksnom parodoncijumu, $\chi^{2}$ testom dobijena je statistički visoko značajna razlika između adekvatne restauracije i zdravog parodoncijuma, odnosno pojave mikrocurenja zbog neadekvatne restauracije i periapikalnih promena $(\mathrm{p}<0,001)$ (Tabela 5).

Kada se sumiraju podaci o pojavi simptoma kod ovih pacijenata, $24 \%$ pacijenata je imalo neki od simptoma zabeleženih nakon inicijalne endodontske terapije, dok je preostalih $76 \%$ slučajeva bilo asimptomatsko. Među pacijentima koji su imali simptome $95 \%$ njih je iz grupe zuba sa promenama u apeksnom parodoncijumu. Fišerovim testom tačne verovatnoće dobijena je statistički značajna razlika u prisustvu simptoma nakon primarne endodontske terapije između zuba sa zdravim parodoncijumom i zuba sa periapiklanim lezijama $(\mathrm{p}=0,019)$ (Tabela 6).

\section{DISKUSIJA}

Ova klinička studija je sprovedena sa ciljem da se analiziraju ishod i uzroci neuspeha primarne endodontske terapije i kliničarima olakša planiranje u slučaju neuspeha inicijalnog endodontskog lečenja. Svi tretirani slučajevi su izdvojeni iz svakodnevne kliničke prakse Klinike za bolesti zuba Stomatološkog fakulteta Univerziteta u Beogradu. Ponovni tretman je realizovan od strane jednog terapeuta.

Pristanak da učestvuje $\mathrm{u}$ istraživanju potpisalo je 37 pacijenata oba pola, starosti od 24 do 79 godina, kod kojih je pažljivim kliničkim i radiografskim pregledom indikovana ponovljena endodontska terapija. Svi pacijenti kod kojih je bilo potrebe za sanacijom neuspele inicijalne endodontske terapije su klinički i radiografski ispitani kako bi se postavila dijagnoza i indikacija za konvencionalni retretman. $U$ istraživanje nisu uključeni pacijenti sa opštim oboljenjima i oni koji su uzimali antibiotsku terapiju u poslednja tri meseca, kao i zubi sa ekstenzivnim karijesnim destrukcijama ili lošim parodontalnim nalazom.

Primarna endodontska terapija je u dva slučaja sprovedena pre manje od godinu dana, u 17 slučajeva $(34,7 \%)$ od jedne do pet godina pre dijagnoze neuspeha prethodnog lečenja, dok je kod 30 zuba (61\%) primarno endodontsko lečenje urađeno pre više od pet godina. Sa aspekta opstanka zuba u usnoj duplji u funkciji vremena, primarna endodontska terapija se može smatrati dugoročno veoma uspešnom. Naime, preko $60 \%$ endodontski lečenih zuba opstalo je u stomatognatnom sistemu vršeći svoju ulogu u mastikaciji duže od pet godina. Salehrabi i Rotstein su 2004. godine sproveli obimnu epidemiološku studiju u Sjedinjenim državama na 1.462.936 zuba. Nakon osam godina 97\% njih je još uvek bilo prisutno u usnoj duplji [4]. S druge 
strane, druge epidemiološke studije poslednjih godina (Boucher i sar. 2002. godine u Francuskoj [27]; Duglas i sar. 2003. godine u Kanadi [28]; Farzenah i sar. 2004. godine u Torontu [29]) ukazuju da preko $30 \%$ endodontski tretiranih zuba pokazuje postojanje hronične periapikalne lezije (apikalnog periodontitisa) ili, po Friedmanu, ,post-treatment endodontic desease “ [1].

Od ukupno 79 zuba, 35\% zuba nije imalo vidljive znake destrukcije periapikalne kosti, dok je kod 65\% zuba registrovano prisustvo hronične periapikalne lezije. PCR analizom uzoraka uzetih iz kanala korena ovih zuba identifikovani su mikroorganizmi u svim uzorcima iz zuba sa promenama u periapikalnim tkivima. Najčešće identifikovani mikroorganizam bio je $E$. Faecalis, detektovan u 94\% kanala korena zuba sa hroničnim periapikalnim lezijama.

Ukoliko bi se kao kriterijum (ne)uspeha primarnog endodontskog tretmana uzela pojava kliničkih simptoma u vidu bola, otoka, postojanja fistule, perkutorne osetljivosti ili bolova na zagrižaj, onda bi to obuhvatilo svega $24 \%$ pacijenata. Najčešći simptomi su bili osetljivost na perkusiju (59\% simptomatskih slučajeva), kao znak hroničnog zapaljenja periodontalnog ligamenta u apiklanoj regiji, i bol (47\% slučajeva), kao znak akutne egzacerbacije hronične periapikalne lezije.

Kada je u pitanju kvalitet opturacije kao faktor uspeha endodontske terapije, kod 79 zuba obrađenih u ovom istraživanju registrovani su neadekvatna opturacija u vidu kratkog punjenja kod 65\% zuba, „zaboravljeni kanali“ (25\% kanala), klinički nehomogeno punjenje $(5,1 \%)$ i prisusutvo frakturiranog instrumenta (3,8\% kanala). Da li nedovoljno napunjen kanal vodi u neuspeh endodontske terapije pre svega zavisi od dijagnoze, odnosno prisustva bakterija u kanalu korena. Ukoliko je endodontski tretman sproveden na vitalnoj pulpi, uz dobru koronarnu restauraciju, nepropusnu za bakterije, do promena u periradikularnim tkivima neće doći. Međutim, kada je u pitanju inficiran kanal korena, prazan prostor u apikalnom delu korena zuba podrazumeva perzistiranje intrakanalne infekcije, odnosno održavanje periradikularne inflamacije nakon završene endodontske terapije [8-15].

Osim apikalne ekstenzije kanalnog punjenja, važan faktor uspeha preduzete endodontske terapije je i gustina, tj. hermetičnost kanalnog punjenja. Nažalost, mikrokompjuterizovane tomografske studije su pokazale da ni najsavremeniji materijali i tehnike instrumentacije i opturacije nisu u mogućnosti da kanal neporozno, odnosno nepropusno za bakterije opturiraju. Hammad i sar. 2009. godine [30], a Zogheib i sar. 2013. godine merili su zapreminski procenat praznina i zarobljenog vazduha $\mathrm{u}$ apikalnoj trećini kanala korena opturisanih tehnikom Termafil (gutaperka i Topseal) i tehnikom opturacije RealSeal (Resilion i RealSeal 1). Nakon skeniranja i merenja zapremine praznina i zjapova u opturisanim kanalima u odnosu na njihovu ukupnu zapreminu došli su do zaključaka da nijedna tehnika opturacije ne omogućava apsolutno hermetičko zaptivanje endodontskog prostora, a da razlika u procentu praznih prostora između novih adhezivnih endodontskih materijala i zlatnog standarda gutaperke nije statistički značajna [31].

Očigledno je da kvalitet opturacije utiče na ishod endodontske terapije, ali da to nije jedini preduslov za uspeh. U ovom istraživanju svi pacijenti sa neadekvatnom opturacijom su upućeni na ponovni endodontski tretman, iako 17,7\% (14 zuba) nije imalo promene u periapikalnim tkivima (PAI 1), dok je kod 17,7\% (14 zuba) postojala neznatno proširena periodontalna membrana (čiji nalaz nije patognomoničan za apikalni periodontitis) (PAI 2). U takvim slučajevima je retretman bio uslovljen potrebom daljeg protetskog zbrinjavanja (kanalnom nadogradnjom) i protetskom nadoknadom, koji onemogućavaju konzervativni retretman ukoliko se naknadno ukaže potreba za tim. Takvi zubi su bili adekvatno restaurisani u 75\% slučajeva ( 21 od 28 zuba). Na taj način je postignuto dobro krunično zaptivanje, koje je maksimalno redukovalo mikrocurenje i na taj način preveniralo (re) infekciju kanala korena i periapeksnih tkiva. Samo jedan zub sa zdravim parodoncijumom nije imao adekvatan ispun i pokazivao je znake akutne infekcije (koja se na radiografiji nije mogla uočiti). Ray i Trope [23] pokazali su da defektne restauracije i adekvatna kanalna punjenja imaju veći procenat neuspeha $\mathrm{u}$ odnosu na zube sa adekvatnim koronarnim restauracijama i neadekvatnim kanalnim punjenjima. Zubi kod kojih su i ispun i opturacija kanala bili adekvatni ukazali su na samo 9\% neuspeha za razliku od zuba kod kojih su i punjenje i restauracija bili defektni, gde je taj procenat iznosio čak $82 \%$. Gillen i sar. su 2011. godine sproveli sistematski pregled dostupne literature na temu uticaja kvaliteta koronarne restauracije i kvaliteta kanalnog punjenja korena endodontski lečenih zuba i metaanalizom podataka došli do zaključka da izgledi za uspeh endodontske terapije rastu ukoliko su i endodontski tretman i krunična restauracija sprovedeni adekvatno, a da kvalitet opturacije kanala i krunične restauracije imaju jednak uticaj na izlečenje [21].

Među zubima sa promenama u apeksnom parodoncijumu bilo je $84 \%$ neadekvatnih restauracija, od čega je $50 \%$ imalo izraženu simptomatologiju, što takođe ukazuje na značaj dobrog rubnog zatvaranja. Do sličnog zaključka su došli i Liang, Wesselink i sar., koji su 2011. godine sproveli radiografsku studiju o preduslovima uspeha poredeći faktore koji se mogu registrovati retroalveolarnom radiografijom i CBCT-om. Na kontrolnom pregledu nakon dve godine od biopulpektomije, retroalveolarnom radiografijom je registrovana pojava periapikalnih lezija u $12,6 \%$, dok je CBCT-om detektovano duplo više hroničnih periapiklanih promena (25,9\%). Zanimljivo je da $80 \%$ punjenja koja su radiografski proglašena „kratkim“, na CBCT-u su bila do apeksnog terminusa. Zaključili su da gustina i apikalna ekstenzija punjenja na retroalveolarnim radiografijama značajno utiču na ishod endodontske terapije. Analizom podataka dobijenih CBCT-om, za uspeh endodotskog tretmana kao presudni faktori su označeni gustina kanalnog punjenja i kvalitet koronarne restauracije [22].

Grupa zuba sa zdravim periodoncijumom obuhvatila je pacijente koji su poslati na ponovni endodontski tretman zbog radiografski neadekvatne opturacije (a u okviru preprotetske pripreme) ili je neuspeh otkriven slučajnim nalazom. Dilema da li zube sa neadekvatnom opturacijom a zdravim parodoncijumom i bez kliničkih znakova i simptoma treba retretirati uvek je aktuelna među endodontistima. Ukoliko zub neće biti deo protetskog rada, može se pratiti redovnim kontroloma, ali ukoliko se planira da zub bude nosač fiksne nadoknade sa intrakanalnom nadogradnjom, svakako treba pokušati „uraditi bolje“ [32]. Osnovni preduslovi za uspešnost endodontskog tretmana u ponovljenom zahvatu vezani su za pravilnu dijagnozu endodontskog neuspeha (Rtg, CBCT), adekvatnu dezopturaciju i preparaciju u ponovnom čišćenju i oblikovanju kanala (stručnost terapeuta, instrumentarijum, materijali), odnosno kvalitetnu trodimenzionalnu hermetičnu opturaciju kanalskog sistema i kvalitetnu, pravovremenu i adhezivnu restauraciju endodontski lečenog zuba u ponovljenom tretmanu. 


\section{ZAKLJUČAK}

$\mathrm{Na}$ ishod endodontskog lečenja značajno utiču kvalitet (hermetičnost) opturacije kanala korena, prisusutvo i kvalitet koronarne restauracije. Većina zuba sa zdravim parodoncijumom, u momentu postavljanja dijagnoze neuspeha primarnog endo- dontskog lečenja bila je adekvatno restaurirana, dok je većina zuba sa obolelim apeksnim parodoncijumom imala neadekvatne krunične restauracije. Kod pacijenata sa simptomima uglavnom su postojale promene $\mathrm{u}$ apeksnom parodoncijumu endodontski lečenih zuba. 